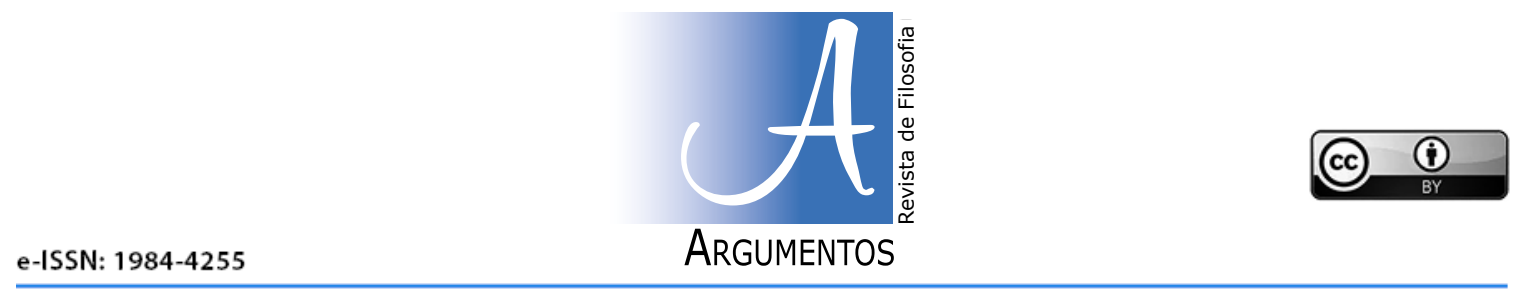

D0I: $10.36517 /$ Argumentos.26.9

\title{
Hannah Arendt and the promises of politics beyond sovereignty
}

\section{Hannah Arendt e a promessa da política além da soberania}

\author{
João Batista Farias Júnior \\ https://orcid.org/0000-0002-2924-5656 - E-mail: joaobfariasjunior@gmail.com
}

\begin{abstract}
Hannah Arendt expresses several critiques of the Western philosophical tradition in her work due to conceptual misunderstandings that played a crucial role in the course of many events in our history. This article attempts to understand how concepts such as power, freedom, and sovereignty appear in Arendt's thinking and shed light on our understanding of politics. Thinking about the relationship between these elements allows us to understand that there are other possibilities for politics besides representative democracies. It is about seeking the centrality of politics as an exercise of freedom that is only possible when we meet and act in concert.
\end{abstract}

Key concepts: Freedom. Power. Sovereignty. Participatory politics.

\section{RESUMO}

Hannah Arendt expressa em suas obras diversas críticas à tradição filosófica ocidental devido a deturpações conceituais que tiveram papel importante no curso de vários acontecimentos de nossa história. O presente artigo busca compreender de que maneira conceitos como poder, liberdade e soberania aparecem no pensamento de Arendt e lançam luz sobre nosso entendimento sobre a política. Pensar a relação entre esses elementos nos permite compreender que existem outras possibilidades para a política além das democracias representativas. Tratase de buscar a centralidade da política enquanto exercício da liberdade que só é possível quando nos reunimos e agimos em concerto.

Palavras-chave: Liberdade. Poder. Soberania. Política participativa. 
Power, freedom, and sovereignty are concepts that have been widely explored by critics and scholars of Hannah Arendt's work. However, it does not mean that all pathways that are possible to read and interpret are closed. As far as this is concerned, we hope to contribute, not in the front of conceptual discussions on these three topics, but rather in what they tie into Arendt's political work: a comprehension of politics that goes far beyond the usual understanding of politics as a system raised on representative sovereignty. To do so, we should focus especially on these works: The Human Condition (1958), Between Past and Future (1961) and On Revolution (1963).

Hannah Arendt usually begins a discussion by presenting what a concept is not. Just as we can attribute the achievement of these conceptual distinctions in part to her philosophical background, it is possible to understand in this same sense that the habit of defining concepts and other intellectual entities in terms of what they are not coming from her critical view of the philosophical tradition. That is, Arendt expresses through her works a critical voice against the Western philosophical tradition because of many conceptual misunderstandings that played an essential role during multiple events in our history. The common understanding of power, freedom, and sovereignty are examples of these distortions. And these three concepts should help us to clarify what kind of political experience Arendt was concerned with.

Political action has as its fundamental characteristics unpredictability and irreversibility. Political action is unpredictable because even the smallest of acts cannot have their results predicted because they always happen among other human beings, and those will always react in an unexpected way to what happens to them. Political action is irreversible because the action, once initiated, no longer belongs to their agents, but to the multiple people who are part of the public space and, for this reason, they can never be undone, since they are continuously attached to other actions and may, therefore, have a long unfolding.

This conception was based on the classic Greek example, yet did not follow along with the tradition of political thought initiated with the philosophies of Plato and Aristotle. Since Plato, says Arendt, politics, like the other activities of the vita activa, had its dignity restricted by being understood as an activity derived from our needs. Plato considered it in this sense, understanding that an activity that demands people's presence could never be truly free. Only the kind of contemplative activity that expected, in a sense, our unconcern with the world and our withdrawal from the presence of other people could be truly free.

Plato, suggesting forms of government to solve the dilemmas of life in common, pointed to the necessary fate: "the banishment of the citizens from the public realm and the insistence that they mind their private business while only 'the ruler should attend to public affairs."' (ARENDT, 1998, p. 221). This proposal by Plato granted to the tradition of Western thought, in addition to the notion of the superiority of absolute quiet of contemplative life over the so-called vita activa, the distinction between the ruler and the ruled in the whole political community. From then on, the idea of representation of those people by the government, regardless of the form of government, became almost a law for the ordinary political understanding.

The tradition of political thought came to experience another significant shift only in the modern era, because of the economic and social transformations brought out by the industrial revolution in Europe. "Despite the precedents in classical political thought, the modern age added particular problems that served to make socio-economic matters much more significant." (LEDERMAN, 2019, p. 154). Society' ${ }^{1}$, a modern invention, had always expected people to move unanimously in favor of the concern raised to the highest degree of interest for all: the economy.

\footnotetext{
1 "Society is the form in which the fact of mutual dependence for the sake of life and nothing else assumes public significance and where the activities connected with sheer survival are permitted to appear in public." (ARENDT, 1998, p. 46).
} 
The most immediate consequence in human affairs of this transformation was that spontaneous action came to be understood as superfluous since the growth of cities and the massification of their population made politics understood as administration the rule.

Still on the characteristics of action, irreversibility and unpredictability, in The Human Condition Arendt writes a topic about the faculty of promise as a political category. According to Arendt, the promise represents a possible remedy for human action, in the sense of bringing a "certain island of predictability" (ARENDT, 1998, p. 244), that is, the promise provisionally dispels the uncertainty inherent to action and allows us to understand what binds us: the prospect look that we share. Arendt says:

The function of the faculty of promising is to master this twofold darkness of human affairs and is, as such, the only alternative to a mastery which relies on the domination of one's self and rule over others; it corresponds exactly to the existence of a freedom which was given under the condition of non-sovereignty. (ARENDT, 1998, p. 244).

We will see next how we can understand this quote as a moment when Arendt makes power, non-sovereignty, freedom, and act converge together ${ }^{2}$. Think of a relationship between these political elements that allows us to understand, along with Arendt, that there are other possibilities for politics besides representative democracies.

\section{Freedom, raison d'être of politics ${ }^{3}$}

"The raison d'être of politics is freedom, and its domain of experience is action" (ARENDT, 1961 , p. 146); with this quote, we can get an idea of the centrality of the concept of freedom in the Arendtian work. Arendt, approaching the Greek political understanding and experience in classical antiquity, defines freedom as the human experience achievable through action and discourse amongst other human beings inside the community we live. Because of the plurality of meanings that have been attributed to "freedom" over the centuries, it is important to say that Arendt does not think that freedom has to do either with the inner life of human beings or with a spiritual phenomenon. The freedom Arendt talks about is the realization of deeds that create, modify and maintain human institutions that relate human beings to each other either on the basis of what they have in common with each other or on the basis of what distinguishes them from each other, which in the end forms a plurality of human beings. In this sense, it is an exercise that takes place in the space in-between that connects and separates.

Freedom had not always featured among the philosophical problems of most significant interests. Its appearance occurred when it was no longer understood as an action in concert. The introduction of freedom in the list of philosophical questions happened when it was taken as a metaphysical question, one of the later ones to appear, given that only after the end of classical antiquity, that is, when the dawn of a Christian philosophy occurred, and what gave

\footnotetext{
${ }^{2}$ It cannot be ignored that Arendt finalizes The Origins of Totalitarianism by relating the end of an event to a new beginning. She says: "But there remains also the truth that every end in history necessarily contains a new beginning; this beginning is the promise, the only "message" which the end can ever produce. Beginning, before it becomes a historical event, is the supreme capacity of man; politically, it is identical with man's freedom. Initium ut esse homo creatus est - "that a beginning be made man was created" said Augustine. This beginning is guaranteed by each new birth; it is indeed every man." (ARENDT, 1973, p. 478-479). The relationship between end and beginning occurs through the establishment of promise as a political category. The promise seals a moment and sheds light on new possibilities.

${ }^{3}$ Despite the title of this topic, we will not say what freedom is for Arendt, since this is a subject that has been widely explored by countless readers of Arendt's work. Rather, we are interested in relating the conditions for the existence of freedom with the notion of power based on the precarious nature of human affairs.
} 
rise to it was the experience of religious conversion. Philosophy has long treated freedom as synonymous with the Christian concept of free will. Contrary to this, Arendt says that people are only free when they are acting, neither before nor after. Since the action is an activity that occurs among humans, it can never be said that someone acted if they are alone or within a type of community where not the plurality, but social unity prevails.

Obviously not every form of human intercourse and not every kind of community is characterized by freedom. Where men live together but do not form a body politic as, for example, in tribal societies or in the privacy of the household the factors ruling their actions and conduct are not freedom but the necessities of life and concern for its preservation. (ARENDT, 1961, p. 148).

The acts and discourses that agents undertake in the public space manifest freedom, which makes the existence of this space effective as a space for the flow of freedom; because of this, if this environment is not protected from any activity that might usurp it, freedom may be usurped with it. Without a proper space for its appearance, freedom becomes only possible in the inner life. Arendt considers that under such conditions we cannot adequately call it freedom because it would be restricted to the human heart, and this is a dark place.

As we mentioned, it was from the moment that freedom ceased to be understood as a synonymous for acting among equals and started to be recognized as a phenomenon of the inner life that philosophers became effectively interested in it. Together with philosophers who thought about political issues, freedom went from being the fundamental mark of action to becoming a sort of sovereignty useful to master virtue. Sovereignty is based on a conception of freedom according to which freedom is the independence of one human being from others and, sooner or later, the prevalence of one human being over others. As the greatest example of this tendency, Arendt cites Rousseau, who formulated his notion of sovereignty from the will.

Politically, this identification of freedom with sovereignty is perhaps the most pernicious and dangerous consequence of the philosophical equation of freedom and free will. For it leads either to a denial of human freedom namely, if it is realized that whatever men may be, they are never sovereign or to the insight that the freedom of one man, or a group, or a body politic can be purchased only at the price of the freedom, i.e., the sovereignty, of all others. (ARENDT, 1961, p. 164).

In this regard, according to Arendt, although for traditional philosophy it is incomprehensible to conceive of the existence of freedom in a space of non-sovereignty - since it associates the simultaneous experience of freedom and sovereignty - , it is dangerous and not very plausible to consider this interdependence, because the sovereignty, in the Arendtian perspective, is conserved by violence apparatus, that is, non-political instruments; and freedom is human action, political life, and therefore does not maintain an identification between the former and the latter ${ }^{4}$. Thus, "If men wish to be free, it is precisely sovereignty they must renounce." (ARENDT, 1961, p. 165).

As stated, in order to clarify those pernicious interpretations of politics, Arendt asserts:

If we look upon freedom with the eyes of the tradition, identifying freedom with sovereignty, the simultaneous presence of freedom and non-sovereignty, of being able to begin

\footnotetext{
${ }^{4}$ Regarding the violent character assumed with the notion of sovereignty, Rubiano (2016, p.163) says that: "Related to the notion of sovereignty, the will, in addition to promoting the identification between being free and being sovereign, made sovereignty to mean governing others as it governs itself, that is, in the mould of the will: when there is an impasse, the will of the ruler must be imposed so that it ends with the others, there is no room for resistance."
} 
something new and of not being able to control or even foretell its consequences, seems almost to force us to the conclusion that human existence is absurd. (ARENDT, 1998, p. 235).

This conclusion, from Arendt's point of view, although not completely wrong, is unfair with the most significant way of human existence, namely, the fact that it is miraculous. Viewing freedom, contrary to this identification with sovereignty in its usual conception, allows us to recognize the miraculous character that human action can bring. The human action, ontologically speaking, is only possible because whenever a human being is born, the ability to start something new is born with her or him, and that is the miracle that the natality and freedom carry. Promises and the willingness to keep them, says Arendt, appears as a kind of remedy for the fate of unpredictability and irreversibility, as we mentioned, and thus are linked to another possibility for politics, other than that advocated by tradition and based on the concept of sovereignty, rather in plurality.

\section{The representative democracy}

Arendtian criticism of representative democracies begins with the distinction that she makes between social and political subjects. In this regard, we can find in The Human Condition her description of how the appearance of the social sphere in modernity resulted in a concomitant reduction for political concerns. Along with the distinction between the social and the political, we must highlight, what we perceive to be more worrying to Arendt, not the simple appearance of these issues in the public realm, but the shrinking of spaces for action and the deep subordination of people to mass movements that make conformity to the bureaucratic representative machine the most straightforward way out. We must mention that Arendt never equated ordinary people with the masses. The term mass is not used by Arendt in a psychological, but in a sociological sense, as the result of the process that socially reduces individuals to the role of voters and consumers whose sole interest is their private affairs.

In The Human Condition, Arendt explores, on the basis of an analysis of three elements that shape part of our existence as human beings, the development of mass society that grows up to the present day. This is because labor, chosen in modernity as the main human activity, starts to condition our existence in such a way that action and work, the other two activities analysed by Arendt in The Human Condition, may respond to its dictates. Following this, it is presented to us as the only possible answer to political dilemmas: the social organization of people encompassing the labor, directing them to the conclusion that representative democracy is the most viable choice for the concretization of our society of workers.

Criticisms of forms of representative democracy, as well as liberalism and party systems, sometimes earned Arendt the nickname of an undemocratic author, which never bothered Arendt, both because of her frequent denial of theoretical frameworks and because of the relative misunderstanding of her accusers of what democracy means ${ }^{5}$. What happens is that, in contrast to the challenge of thinking about the plural participation of human beings in the public sphere, the diffusion of the idea of democratic representation distances us precisely from the reason for being of politics, that is, of the freedom that only it is possible through action taken in the middle and in concert with other beings.

\footnotetext{
5 Cf. Isaac (1994, p. 156).
} 
In On Revolution, Arendt attempts to rescue the "lost treasure of revolutions" that has allowed some people on rare occasions to experience public happiness. This treasure, however, was buried, on the one hand, by the totalitarian experience with Stalinism, and on the other, by the usurpation of public happiness by private happiness. And it was the latter that became the rule and main engine for the globalization of liberal representative democracies.

Representative democracy cannot provide the experience of a plurality of perspectives for the majority of its citizens. Therefore, representative democracy disrupts proper opinion formation on political topics. In fact, according to Arendt, in the specific sense of the term, "opinions" simply do not exist in representative democracy. (SITTON, 1987, p. 84).

The hope that some representative government can handle the management of the political issues is based on the understanding that politics does not require a plurality of human beings, but only one individual to decide for others. In that case, freedom is easily rejected because of a movement to reduce the citizen to a private self. Arendt's critique of representative democracies, based on this utopian understanding, resides in the small role left to the participation of people in the deliberations of common issues.

\footnotetext{
The most the citizen can hope for is to be "represented", whereby it is obvious that the only thing which can be represented and delegated is interest, or the welfare of the constituents, but neither their actions nor their opinions. In this system the opinions of the people are indeed unascertainable for the simple reason that they are non-existent. Opinions are formed in a process of open discussion and public debate, and where no opportunity for the forming of opinions exists, there may be moods-moods of the masses and moods of individuals, the latter no less fickle and unreliable than the former-but no opinion. (ARENDT, 1990, p. 268-269).
}

Politics occurs through the public sphere, in which each participant reveals his or her true self either through their actions or their discourses, which does not meet the notion of representativeness. It does not matter if the notion of sovereignty is defended through the representation of a chosen individual or a political institution with a larger number of members, it will always be an eradication of plurality. As plural beings, unique and yet capable of understanding and recognizing each other, we need a space to appear to each other, discuss our opinions on common subjects, and truly participate in the human world. A circumstance that no representation can replace.

Sovereignty is contrary to the undeniable fact of plurality, on account of which one human could never be a sovereign, since a plurality of humans inhabit the Earth, and not just one. And this fact, Arendt recalls, need not be understood as a "limitation of human's vigor" as Plato did, who saw plurality as a necessity, a type of weakness, which required the coexistence of several people in favor of mutual assistance. Instead, plurality is the mark that even though we are part of the same species, we are distinct from each other.

Plurality, besides being a basic condition for action, can inspire us to imagine different forms of politics, giving up representative sovereignty. This inspiration allows us to move from Arendt's criticism to representative democracies to the analysis of revolutions and some unique experiences of direct participation that greatly influenced Arendt from the 1960s. Until 1958 when Arendt published The Human Condition, where we got the first quote used here, she had not yet addressed the case of councils, which arose mainly in the early years of the Russian revolutions of 1905 and 1917, which she was aware of mainly through living with Heinrich Blücher, her second husband, who was close to several revolutionary movements in Germany 
who were defenders of the importance of councils and assemblies ${ }^{6}$. That same year, Arendt published an article entitled "Totalitarian Imperialism: Reflections on the Hungarian Revolution". Next, we will see how these councils and assemblies accentuate the experience of a participatory policy as something to be remembered, sought after and exercised.

\section{From non-sovereignty to politics}

As stated by Shmuel Lederman (2019, p. 21), it is necessary to underline that Arendt's critique of sovereignty is not only directed internally at a community, a political institution or even at a nation-state. The external sovereignty must also be renounced if among the political principles of a certain group is the worship, for example, of the commitment to the recognition of human rights internationally.

Arendt criticizes, as we have seen, not the idea of democracy per se, but the type of representative democracy that has been implemented since modernity in European and American countries. Representativeness in politics, says Arendt, especially in the model of modern party democracy, allows only those who are elected, that is, the representatives, to experience the action.

Let us move beyond this small politics - in the Nietzschean sense - and examine how Arendt harnesses the notion of promise cited in the first chapter of this text to conceive a singular form of association from which emerges a type of sovereignty that allows people to congregate around a promise, in contrast to paradigmatic sovereignty that segregates the space of action for a distinct minority.

The sovereignty of a body of people bound and kept together, not by an identical will which somehow magically inspires them all, but by an agreed purpose for which alone the promises are valid and binding, shows itself quite clearly in its unquestioned superiority over those who are completely free, unbound by any promises and unkept by any purpose. This superiority derives from the capacity to dispose of the future as though it were the present, that is, the enormous and truly miraculous enlargement of the very dimension in which power can be effective. (ARENDT, 1998, p. 245).

Sovereignty, as Arendt conceives in this passage from The Human Condition, cannot be identified as a characteristic of a State or of an individual; on the contrary, it manifests itself whenever different people come together in concert action. There is a very dear example to Arendt that is undoubtedly a treasure left by some successful revolutionary movements: the council systems.

Arendt was impressed by the spontaneous character present in the rise of councils and soviets. In Hungary, various councils emerged from different groups of people, from councils formed by neighbourhood residents, to councils of writers and artists, students, workers, and other groups of workers and, finally, civilians more directly engaged with the revolution. In Russia, they mainly took the form of councils of workers, peasants, and soldiers.

The most striking aspect of these spontaneous developments is that in both instances it took these independent and highly disparate organs no more than a few weeks, in the case of Russia, or a few days, in the case of Hungary, to begin a process of co-ordination and integration through the formation of higher councils of a regional or provincial character,

6 Cf. Lederman (2019, p. 2). 
from which finally the delegates to an assembly representing the whole country could be chosen. (ARENDT, 1990, p. 267).

This unique experience, which was applauded by Arendt at once, allows us to question the need for categories such as sovereignty and representativeness, as well as illuminates how revolutionary spontaneity makes popular participation flourish. This spontaneous character in the emergence of council systems in Hungary deserves to be mentioned, as Arendt also does the pre-revolutionary debates in the United States and France with the experience of the Paris Commune, therefore, considering the faculty of action as founded ontologically in the birth, acting seems so spontaneous that it could be said to be a true miracle. A kind of miracle that allows us to understand our ability to start something new and, in concert with other human beings, not only to interrupt the imposing force of the life cycle, but to experience freedom in a space of plurality.

Unlike some of her fellow philosophers who tried to offer some kind of prêt-à-porter political models, Arendt did not devise a political program to be followed. We find, rather, in her work an invitation to think about politics in a much more participatory terms than those currently offered in liberal democracies, symbols of a "representative sovereignty" that remove the meaning of public space, the visibility of the plurality of men and women, as well as it diminishes the political action of its content, the exercise of freedom.

\section{Politics beyond sovereignty}

Since Arendt, participatory politics has inspired several thinkers, especially because many recent events and protest movements reinforce the thesis of our thinker's oeuvre. In this sense, we find it pertinent to point out the recent work of Judith Butler, Notes Toward a Performative Theory of Assembly (2015), as a reading that continues the discussion here undertaken about the work of Hannah Arendt. Butler, who, since the introduction of this work, admits that she is dialoguing with Arendt, rethinks, especially from the most recent political events, concepts such as freedom, the public and private spaces, the assemblies and the very notion of politics.

In the light of assemblies arising from events such as the Arab Spring and the Occupy Wall Street movement, Butler calls into question our most traditional understandings concerning politics. These recent assemblies, says Butler, have pointed out the inconsistency of representation as a political category, in addition to vigorously demonstrating alternative forms of political action. Recent technology, recalls Butler, also contributes to social and political movements, either by publicizing these events or by building relative dialogues, as well as by capturing the police's brusque reactions. In this regard, Butler has slightly broader notions than Arendt's, taking performativity as a possible political action even in silence, in an anonymous, solitary, and even in a virtual space?

Asserting that a group of people is still existing, taking up space and obdurately living, is already an expressive action, a politically significant event, and that can happen wordlessly in the course of an unpredictable and transitory gathering. Another "effective" result of such plural enactments is that they make manifest the understanding that a situation is shared, contesting the individualizing morality that makes a moral norm of economic

\footnotetext{
${ }^{7}$ As for the understanding of the political action at stake in the revolutionary councils, according to Shmuel Lederman, Arendt had distorted the importance of the social and economic issues that were on the scene together with those of a political character, since one of the main claims of the workers was precisely to overcome this division between politics and economics and take control of production processes. Cf. Lederman (2019, p. 180).
} 
self-sufficiency precisely under conditions when self-sufficiency is becoming increasingly unrealizable. Showing up, standing, breathing, moving, standing still, speech, and silence are all aspects of a sudden assembly, an unforeseen form of political performativity that puts liveable life at the forefront of politics. (BUTLER, 2015, p. 18).

It can be said that the spontaneous and miraculous union of these participants amounts to a promise which is asserted by the shouts, the slogans and the silence of these people against the various forms of domination and government which massacre them. Both the democratic councils that emerged from the revolutions that Arendt witnessed and highly esteemed, and the assemblies that emerged during events of these first two decades of the 21 st century that Butler brings us as examples of effective participatory democracy, show us that there are still several possibilities for politics and, mainly, to renew freedom through action in concert and, maybe, a more contemporary notion of power.

Freedom is at stake and the many demonstrations and assemblies shows that the struggle for the reinvention of politics and public space is crucial in our time. We cannot say when and in what ways these reinventions will occur, but if we have the human capacity to start something new, we will have the possibility to see politics as plural as the forms of life.

\section{References}

ARENDT, Hannah. Between Past and Future: six exercises in political thought. New York: The Viking Press, 1961.

ARENDT, Hannah. On Revolution. London: Penguin Books, 1990.

ARENDT, Hannah. The Human Condition. Chicago: UCP, 1998.

BUTLER, Judith. Notes Toward a Performative Theory of Assembly. London: HUP, 2015.

ISAAC, Jeffrey C. Oases in the Desert: Hannah Arendt on Democratic Politics. The American Political Science Review, v. 88, n. 1, march 1994, p.156-168.

LEDERMAN, Shmuel. Hannah Arendt and Participatory Democracy: a people's utopia. Cham: Palgrave Macmillan, 2019.

RUBIANO, Mariana de Mattos. Revolução em Hannah Arendt: compreensão e história. 2016. Tese (Doutorado em Filosofia). Faculdade de Filosofia, Letras e Ciências Humanas, Universidade de São Paulo, São Paulo, 2016.

SITTON, John F. Hannah Arendt's Argument for Council Democracy. Polity, v. 20, n. 1, Autumn 1987, p. 80-100.

WOLIN, Sheldon S. Hannah Arendt: democracy and the political. Salmagundi, n. 60, SummerSpring 1983, p. 3-19. 


\section{Sobre o autor}

\section{João Batista Farias Júnior}

Doutorado em Filosofia pela Universidade Federal de Goiás (UFG). Professor do Instituto Federal de Educação, Ciência e Tecnologia do Piauí.

Recebido em: 30/09/2020.

Aprovado em: 11/02/2021.
Received: 30/09/2020.

Approved: 11/02/2021. 